\title{
Efektivitas Daun Jarak (Jatropha curcass Linn) Sebagai Anticacing Ascaridia galli dan Pengaruhnya terhadap Performa Ayam Lokal
}

\author{
Effectiveness of Jatropha curcass Linn Leaves as an Anthelmintic for Ascaridia galli and its Effect on \\ Native Chicken Performance
}

\author{
S. Suhartia ${ }^{*}$, K. G.Wiryawan ${ }^{a}$, R. Tiuria ${ }^{b}$, Y. Ridwan $^{b}$, S. Fitriana ${ }^{a}$, \& N. Sumarni ${ }^{a}$ \\ ${ }^{a}$ Departemen Ilmu Nutrisi dan Teknologi Pakan, Fakultas Peternakan, Institut Pertanian Bogor \\ ${ }^{b}$ Fakultas Kedokteran Hewan, Institut Pertanian Bogor \\ Jln. Agatis, Kampus IPB Darmaga, Bogor 16680 \\ (Diterima 31-08-2010; disetujui 06-01-2010)
}

\begin{abstract}
The present experiment was aimed to identify the phytochemical of Jatropha curcas leave extracted with water and methanol as an anthelmintic agent for Ascaridia galli, and its effect on native chicken performance. In vitro study of anthelmintic activity was conducted by counting the number of paralyzed worm dead-body of $A$. galli during 18 hours in petri dish containing different levels of extract, namely $0 \%, 1 \%, 2 \%, 3 \%$, and $4 \%(\mathrm{w} / \mathrm{v})$ and compared to the piperazine $0.5 \%(\mathrm{w} / \mathrm{v})$. Eightteen birds of naturally $A$. galli-infected native chicken were used for the in vivo study. The treatments were $0 \%, 2 \%, 4 \%, 8 \%$, and $16 \%$ of $J$. curcass leave extract, and $10 \%$ of piperazine using a completely randomized block design with 6 treatments and 3 replications. Parameters observed were fecal worm egg count, feed consumption, body weight gain, feed conversion ratio, and mortality. The results showed that water- and methanol-extracted J. curcas leave had similar composition of secondary metabolite compounds which is high in triterpenoid and steroid contents, respectively. Percentage of paralyzed $A$. galli was higher $(\mathrm{P}<0.01)$ in water-extracted jatropha leaves. On the contrary, the deadbody percentage was higher $(\mathrm{P}<0.05)$ in the methanol-extracted than that in the control group. In vivo study showed that leave meal significantly decreased $(\mathrm{P}<0.05)$ fecal worm egg count. The leaf meal at the level $16 \%$ tended to increase feed consumption, body weight gain, and significantly decreased feed conversion ratio. In conclusion, J. curcas leave meal have anthelmintic activity to A. galli and could improve nutrient utilization of naturally $A$. galli-infected native chicken by decreasing feed conversion ratio.
\end{abstract}

Key words: J. curcass leave, A. galli, growth performance, native chicken

\section{PENDAHULUAN}

Berkembangnya cacing Ascaridia galli dalam saluran pencernaan ayam lokal dapat menurunkan produktivitas. Konversi ransum menjadi lebih besar, sehingga penggunaan ransum kurang efisien. Pertumbuhan ayam lokal yang terinfeksi cacing $A$. galli menjadi turun hingga $38 \%$ sehingga menghasilkan bobot badan yang rendah (Tabbu, 2002).

Usaha pengendalian infeksi cacing yang efektif adalah dengan memadukan antara manajemen peternakan yang baik dan pemberian anticacing. Anticacing yang banyak beredar di pasaran dalam bentuk sintetis harganya relatif mahal. Penggunaan obat cacing terse-

* Korespondensi:

Departemen Ilmu Nutrisi dan Teknologi Pakan, Fakultas Peternakan, Institut Pertanian Bogor

Jln. Agatis, Kampus IPB Darmaga, Bogor 16680

e-mail: sri_suharti@ipb.ac.id but dalam waktu lama dapat menimbulkan resistensi cacing serta adanya kekhawatian residu pada produk ternak. Anticacing alternatif yang berasal dari tanaman obat (herbal) dengan harga murah dan mudah didapat, perlu dikembangkan sebagai antisipasi masalah di atas. Upaya tersebut dapat menambah kasanah keragaman obat cacing dan menghindari efek residu dari obat cacing sintetis.

Daun jarak merupakan salah satu bahan alami yang diduga dapat digunakan sebagai anticacing karena mengandung senyawa metabolit sekunder seperti alkaloid, saponin, tanin, fenolik, flavonoid, triterpenoid, steroid, dan glikosida. Senyawa tersebut terutama tanin diharapkan dapat digunakan sebagai anticacing A. galli pada ayam lokal. Daun jarak dilaporkan dapat menghambat pertumbuhan cacing Ascaris lumbricoides (Fagbenro-Beyioku et al., 1998). Adanya kesamaan jenis antara kedua cacing tersebut, yaitu sama-sama dari jenis Ascaris, diharapkan daun jarak juga dapat berkhasiat sebagai anticacing $A$. galli. 
Penggunaan senyawa sekunder tanaman untuk mengontrol infeksi cacing sudah banyak diteliti pada ternak ruminansia kecil (domba dan kambing). Oliveira et al. (2009) melaporkan aktivitas anti cacing Haemonchus contortus dari buah Cocos nucifera yang dapat menghambat penetasan telur cacing $100 \%$ dan pertumbuhan larva 99,77\% secara in vitro. Selanjutnya, Ademola et al. (2004) menyatakan bahwa ekstrak dari tanaman Khaya senegalensis dapat menurunkan viabilitas dari larva nematoda saluran pencernaan ternak ruminansia dengan lethal concentration fifty $\left(\mathrm{LC}_{50}\right)$ sebesar $0,69 \mathrm{mg} / \mathrm{ml}$. Sementara itu, domba yang diberi ekstrak K. senegalensis $500 \mathrm{mg} / \mathrm{kg}$ ransum dapat menurunkan total telur dalam feses sebesar $88,2 \%$.

Penelitian ini bertujuan untuk mengidentifikasi jenis senyawa fitokimia pada daun jarak, menentukan konsentrasi ekstrak daun jarak (EDJ) yang paling efektif sebagai anticacing terhadap cacing A. galli secara in vitro, serta mengevaluasi pengaruh pemberian tepung daun jarak (TDJ) dalam air minum terhadap performa ayam lokal.

\section{MATERI DAN METODE}

\section{Pengadaan Cacing Ascaridia galli}

Cacing A. galli dewasa dikumpulkan dari usus ayam lokal dari tempat pemotongan ayam di Bogor. Usus halus dibuka dengan gunting secara aseptis, cacing diambil dari dalam lumen dengan menggunakan pinset dan dimasukkan ke dalam tabung film yang berisi larutan $\mathrm{NaCl}$ fisiologis. Cacing yang diperoleh dicuci dan dibilas berulang-ulang hingga bersih dengan larutan $\mathrm{NaCl}$ fisiologis.

\section{Pengolahan dan Ekstraksi Daun Jarak serta Penapisan Fitokimia}

Komponen bioaktif daun jarak didapatkan melalui proses ekstraksi yang diawali dengan pembuatan tepung. Tahapan pengolahannya adalah sebagai berikut, daun jarak dibersihkan, kemudian dikeringanginkan selama 30-36 jam dan selanjutnya dikeringkan dengan oven selama 6 jam pada suhu $45^{\circ} \mathrm{C}$. Daun yang telah dioven, digiling sehingga menghasilkan tepung/serbuk yang berukuran 60 mesh. Sampel yang telah berbentuk serbuk diekstraksi dengan teknik maserasi/perendaman. Pelarut yang digunakan adalah metanol 96\% dan air. Perbandingan tepung daun jarak dengan metanol dan air masing-masing 1:3 dan 1:7. Perendaman dilakukan di atas shaker selama 2 jam kemudian didiamkan selama 12 jam. Hasil ekstraksi selanjutnya disaring, dan bagian larutan diuapkan dengan menggunakan rotary evaporator sampai metanol dan air menguap habis, kemudian dikeringkan dengan oven pada suhu $60{ }^{\circ} \mathrm{C}$ sampai didapatkan bentuk ekstrak kering (Kalia et al., 2008).

Daun jarak yang telah diekstraksi diuji kandungan kimianya untuk mengetahui golongan senyawa aktif yang terkandung di dalamnya. Berdasarkan perbedaan polarity (sifat polaritas) pelarut yang digunakan maka uji golongan senyawa dilakukan menurut polaritas zat terlarut dengan pelarut. Setiap EDJ diuji terhadap adanya golongan senyawa alkaloid, flavonoid, steroid/ triterpenoid, saponin dan tanin. Penapisan fitokimia dilaksanakan di Laboratorium Kimia Analitis, Departemen Kimia, Fakultas Matematika dan Ilmu Pengetahuan Alam IPB.

\section{Uji Aktivitas Anticacing secara in Vitro}

Cawan petri yang telah berisi $20 \mathrm{ml} \mathrm{NaCl}$ fisilogis ditambah EDJ sehingga konsentrasi akhir menjadi 0, $1,2,3$, dan $4 \% \mathrm{~b} / \mathrm{v}$, dan sebagai pembanding disiapkan juga cawan petri yang sama ditambah larutan piperazin 0,5\% b/v. Sebanyak lima ekor cacing tanpa membedakan jenis kelamin, dengan asumsi berat dan panjang sama, dimasukkan ke dalam setiap cawan petri. Waktu paralisis dan jumlah cacing yang lisis diamati setiap satu jam selama 18 jam. Cacing $A$. galli dewasa dapat dinyatakan paralisis apabila tidak adanya gerakan oleh ransangan sentuhan. Penelitian disusun dalam rancangan acak lengkap (RAL) yang terdiri atas 10 perlakuan, dengan 3 ulangan setiap perlakuan (Mattjik \& Sumertajaya, 2002).

\section{Evaluasi Pengaruh Pemberian Tepung Daun Jarak (TDJ) dalam Air Minum terhadap Performa Ayam Lokal in Vivo}

Ternak yang digunakan dalam penelitian ini adalah 18 ekor ayam lokal umur 2-3 bulan yang terinfeksi cacing A. galli secara alami dengan bobot badan berkisar 445-970 g. Ayam lokal dibeli di Pasar Anyar Kodya Bogor, selanjutnya dipelihara selama lima minggu dalam kandang battery yang telah difumigasi sebelumnya. Kandang terdiri atas 18 petak dan setiap petak berukuran $45 \times 45 \times 35 \mathrm{~cm}$ untuk satu ekor ayam. Setiap petak kandang dilengkapi dengan satu tempat pakan dan tempat air minum. Ransum penelitian yang digunakan berdasarkan nisbah energi metabolis $(2.900$ $\mathrm{kkal} / \mathrm{kg}$ ) dan protein (16\%) menurut rekomendasi NRC (1994). Bahan baku ransum terdiri atas jagung kuning, pollard, bungkil kedelai, tepung ikan, minyak kelapa, $\mathrm{CaCO}$, dicalcium phospate (DCP), DL-metionina, L-lisina, dan premiks, diperoleh dari PT. Indofeed- Bogor. Ransum dan air minum diberikan ad libitum. Ransum perlakuan mengandung protein kasar $17 \%$, serat kasar 2,4\%, dan energi bruto $3924 \mathrm{kkal} / \mathrm{kg}$ (Hasil Analisis Laboratorium Ilmu dan Teknologi Pakan, Fakultas Peternakan, Institut Pertanian Bogor).

Penelitian menggunakan rancangan acak kelompok terdiri atas enam perlakuan dan tiga kelompok bobot badan, yaitu bobot badan rendah (445-640 g), sedang (670-710 g), dan tinggi (695-970 g) dengan satu ekor ayam sebagai satuan percobaan. Perlakuan yang diuji adalah pencekokan tepung daun jarak (TDJ) yang dilarutkan dalam air minum dengan konsentrasi sebagai berikut :

R1 : Ransum basal + tanpa TDJ (kontrol negatif)

R2 : Ransum basal + pencekokkan TDJ 2\% (b/v)

R3 : Ransum basal + pencekokkan TDJ 4\% (b/v)

R4 : Ransum basal + pencekokkan TDJ 8\% (b/v)

R5 : Ransum basal + pencekokkan TDJ 16\% (b/v)

R6 : Ransum basal + pencekokkan larutan piperazin $10 \%$ (kontrol positif) 
Perlakuan diberikan selama satu minggu setiap pagi sebelum ayam diberi ransum dan air minum, dengan cara mencekokkan $1 \mathrm{ml}$ ekstrak tepung daun jarak berbagai konsentrasi dengan menggunakan spuit tumpul. Pencekokkan dimaksudkan agar senyawa bioaktif yang terdapat pada tepung daun jarak cepat larut dalam air sehingga cepat berpengaruh dalam tubuh ternak. Parameter yang diamati adalah total telur dalam tiap gram ekskreta (TTGE), konsumsi ransum, pertambahan bobot badan (PBB), konversi ransum, dan mortalitas.

\section{Pemeriksaan Kecacingan}

Pemeriksaan kecacingan dilakukan beberapa hari sebelum perlakuan untuk memastikan bahwa ternak tersebut terinfeksi cacing $A$. galli. Lima gram feses diambil dari ternak kemudian diperiksa dengan menggunakan metode Mc. Master yang dimodifikasi (Cringoli et al., 2004). Dua gram tinja dilarutkan ke dalam $58 \mathrm{ml}$ larutan pengapung yang kemudian disaring dan dihomogenkan kembali kemudian dimasukkan ke dalam kamar hitung Mc. Master. Kamar hitung diperiksa di bawah mikroskop untuk mengetahui jumlah telur di dalamnya. Larutan pengapung terdiri atas campuran 400 g garam dan 500 g gula yang dilarutkan pada 1 liter air. Campuran garam, gula dan air diaduk hingga homogen dan menjadi larutan jenuh dengan berat jenis 1,280 .

Pemeriksaan kecacingan dilakukan kembali setelah seminggu perlakuan karena pada siklus hidupnya, telur cacing yang dikeluarkan bersama feses membutuhkan waktu 8-10 hari untuk menjadi telur cacing infektif. Pemeriksaan kecacingan ini dilakukan untuk mengetahui pengaruh pemberian tepung daun jarak terhadap jumlah telur cacing dalam tiap gram ekskreta.

\section{Analisis Data}

Data yang diperoleh dianalisa dengan analysis of variance (ANOVA). Data hasil in vitro (satuan persen) ditransformasi akar kuadrat terlebih dahulu sebelum dianalisa dengan ANOVA. Analisis lanjut dilakukan menggunakan regresi linier untuk mengetahui hubungan konsentrasi ekstrak tepung daun jarak dengan persentase kematian cacing (Mattik \& Sumertajaya, 2002).

\section{HASIL DAN PEMBAHASAN}

\section{Ekstraksi, Rendemen, dan Penapisan Fitokimia}

Proses ekstraksi daun jarak dilakukan secara bertingkat mulai dari pelarut metanol diikuti oleh pelarut air, dengan tujuan untuk memisahkan fraksi yang memiliki pelarut dengan tingkat polarisasi yang berbeda. Metanol dapat melarutkan senyawa semi polar, dan air melarutkan senyawa polar. Rendemen dari ekstraksi menggunakan pelarut air lebih banyak (2,51\%) dibandingkan dengan pelarut metanol (0,49\%) (Tabel 1). Kopkhar (2002) menyatakan bahwa kelarutan senyawa dalam air atau alkohol lebih ditentukan oleh kemam-
Tabel 1. Rendemen dan hasil penapisan fitokimia ekstrak daun jarak (EDJ)

\begin{tabular}{lcc}
\hline \multirow{2}{*}{ Jenis zat aktif } & \multicolumn{2}{c}{ Bahan pelarut } \\
\cline { 2 - 3 } & Air & Metanol \\
\hline Rendemen (\%)* & 2,51 & 0,49 \\
Golongan senyawa : & & \\
Alkaloid & ++++ & ++++ \\
Saponin & ++++ & +++ \\
Tanin & ++ & ++++ \\
Fenolik & + & + \\
Flavonoid & ++++ & ++ \\
Triterpenoid & ++++ & - \\
Steroid & - & ++++ \\
Glikosida & ++++ & ++++ \\
\hline
\end{tabular}

Keterangan: $(-)=$ negatif/tidak ada, $(+)=$ rendah, $(++)=$ sedang, $(+++)=$ kuat, $(+++)=$ kuat sekali. ${ }^{*}: \mathrm{b} / \mathrm{b}(\mathrm{g} / \mathrm{kg})$

puan senyawa tersebut membentuk ikatan hidrogen. Ikatan hidrogen lebih mudah terbentuk di dalam air, sehingga zat aktif yang terdapat pada daun jarak lebih mudah larut dalam air dibanding di dalam metanol.

Penapisan fitokimia terhadap EDJ dilakukan untuk mengetahui jenis senyawa metabolit sekunder yang terkandung dalam setiap bahan yang diuji. Hasil ekstrak menggunakan air mengandung senyawa triterpenoid dalam jumlah besar dan tidak terdapat steroid, sedangkan ekstraksi memakai metanol kaya akan steroid dan tidak mengandung triterpenoid (Tabel 1).

\section{Aktivitas Anticacing Ekstrak Daun Jarak (EDJ) in Vitro}

Aktivitas anticacing terkuat ditemukan pada EDJ menggunakan pelarut air, diikuti dengan pelarut metanol (Tabel 2). Perbedaan aktivitas anticacing tersebut disebabkan oleh kelarutan senyawa sekunder dalam EDJ memakai pelarut air lebih tinggi dibanding pelarut metanol. Pernyataan Kopkhar (2002) memperkuat hasil penelitian ini bahwa kelarutan senyawa pada air atau alkohol lebih ditentukan oleh kemampuan senyawa tersebut membentuk ikatan hidrogen. Ikatan hidrogen lebih mudah terbentuk di dalam air, sehingga senyawa bioaktif yang terdapat pada daun jarak lebih mudah larut dalam air dibanding di dalam metanol, pada akhirnya efektivitas anti cacing lebih tinggi.

Kematian cacing $A$. galli (Tabel 2) yang direndam dengan EDJ menggunakan pelarut air pada konsentrasi $1 \%, 2 \%$, 3\%, dan $4 \%$ berturut-turut adalah 5 ekor (33,3\%), 11 ekor $(73,3 \%), 12$ ekor $(80,0 \%), 13$ ekor $(86,7 \%)$. Cacing A. galli $100 \%$ mati pada kelompok kontrol positif (piperazin 0,5\%), tetapi tidak ada cacing yang mati pada perlakuan $\mathrm{NaCl}$ fisiologis (tanpa EDJ). Hal ini menunjukkan bahwa semakin tinggi konsentrasi EDJ dalam pelarut air yang digunakan maka persentase kematian cacing juga semakin meningkat.

Ekstraksi menggunakan metanol juga nyata meningkatkan kematian cacing $A$. galli dibandingkan per- 
lakuan kontrol. Semakin tinggi konsentrasi EDJ, jumlah kematian cacing meningkat, kecuali perlakuan dengan $3 \%$ EDJ menunjukkan penurunan kematian cacing. Hal ini diduga adanya sebagian zat aktif pada EDJ dengan metanol yang tidak larut dengan sempurna, sehingga efek zat aktif tersebut berkurang dan menurunkan jumlah kematian cacing. Terdapat perbedaan yang sangat nyata antara kontrol positif (piperazin) dengan EDJ yang digunakan (pelarut air dan metanol). Piperazin memiliki sifat anticacing yang paling kuat. Adanya perbedaan yang sangat nyata antara piperazin dengan EDJ karena konsentrasi EDJ yang digunakan masih rendah, bila konsentrasi ditingkatkan kemungkinan efek anticacing EDJ mendekati piperazin.

Hasil uji kontras menunjukkan perbedaan yang sangat nyata $(\mathrm{P}<0,01)$ antara perlakuan tanpa penambahan EDJ (menggunakan $\mathrm{NaCl}$ fisiologis) dengan pengobatan yang diberikan (menggunakan piperazin dan EDJ). Hal ini disebabkan $\mathrm{NaCl}$ fisiologis merupakan suatu larutan yang diibaratkan sama de-ngan kondisi tubuh ternak, sehingga cacing masih bisa bertahan hidup. Penambahan EDJ dengan berbagai konsentrasi menimbulkan pengaruh lethal terhadap cacing.

Hasil uji kontras menunjukkan bahwa EDJ dengan pelarut air nyata $(\mathrm{P}<0,01)$ lebih tinggi aktivitas anticacingnya dibandingkan EDJ dengan pelarut metanol. Hal ini terjadi karena pengaruh perbedaan senyawa metabolit sekunder dalam masing-masing ekstrak. Berdasarkan hasil uji fitokimia daun jarak yang diekstraksi dengan air mengandung triterpenoid dan bukan steroid, sedangkan daun jarak yang diekstraksi dengan metanol mengandung steroid. Daun jarak yang diekstraksi dengan pelarut air sangat nyata $(\mathrm{P}<0,01)$ meningkatkan jumlah kematian cacing dibandingkan dengan pelarut metanol. Sementara itu, pemberian EDJ dengan pelarut air pada level 1\% sangat nyata $(\mathrm{P}<0,01)$ meningkatkan kematian cacing dibandingkan

Tabel 2. Hasil uji aktivitas anticacing ekstrak daun jarak (EDJ) dengan pelarut air dan metanol secara in vitro terhadap paralisis cacing Ascaridia galli selama 18 jam

\begin{tabular}{lcc}
\hline \multirow{2}{*}{\multicolumn{1}{c}{ Perlakuan }} & \multicolumn{2}{c}{$\begin{array}{c}\text { Jumlah cacing yang } \\
\text { paralisis }\end{array}$} \\
\cline { 2 - 3 } & Ekor & $(\%)$ \\
\hline Tanpa EDJ (NaCl fisiologis) & $0(15)$ & 0,0 \\
Piperazin/obat cacing (0,5\%) & $15(15)$ & 100,0 \\
EDJ dengan pelarut air 1\% & $5(15)$ & $33,3^{\mathrm{a}}$ \\
EDJ dengan pelarut air 2\% & $11(15)$ & $73,3^{\mathrm{b}}$ \\
EDJ dengan pelarut air 3\% & $12(15)$ & $80,0^{\mathrm{b}}$ \\
EDJ dengan pelarut air 4\% & $13(15)$ & $86,7^{\mathrm{b}}$ \\
EDJ dengan pelarut metanol 1\% & $6(15)$ & 40,0 \\
EDJ dengan pelarut metanol 2\% & $6(15)$ & 40,0 \\
EDJ dengan pelarut metanol 3\% & $5(15)$ & 33,3 \\
EDJ dengan pelarut metanol 4\% & $10(15)$ & 66,7 \\
\hline
\end{tabular}

Keterangan: superskrip dengan huruf kapital berbeda menunjukkan berbeda sangat nyata $(\mathrm{P}<0,01)$. Nilai di dalam kurung menunjukkan jumlah cacing yang digunakan untuk tiga ulangan. dengan level 2\%, 3\%, dan 4\%. Namun demikian, pada level $2 \%$ sampai dengan $4 \%$ menunjukkan tidak terdapat perbedaan yang nyata. Hal ini menunjukkan bahwa pemberian EDJ dalam pelarut air sampai level $4 \%$ memberikan dampak yang hampir sama dengan penggunaan EDJ 2\%.

Kemampuan anticacing EDJ dengan pelarut air membentuk kurva kuadratik dengan persamaan $\mathrm{Y}=$ $-6,1786 X^{2}+46,724 X-1,7171$ dan $R^{2}=0,9851$. Nilai $Y$ adalah persentase kematian cacing dan nilai $\mathrm{x}$ adalah level EDJ dengan pelarut air yang dinyatakan dalam persen. Korelasi positif tampak sangat nyata $(\mathrm{P}<0,01)$ antara konsentrasi EDJ menggunakan pelarut air dengan persentase kematian cacing. Hal ini berarti adanya peningkatan persentase jumlah kematian cacing akibat peningkatan konsentrasi EDJ. Kurva kuadratik yang terbentuk menunjukkan bahwa penggunaan EDJ dengan pelarut air pada level $4 \%$ memberikan hasil yang sama dengan penggunaan EDJ $2 \%(P>0,05)$. Dengan demikian, kemampuan anticacing EDJ dengan pelarut air pada level $4 \%$ tidak berbeda dengan level $2 \%$.

Senyawa metabolit sekunder yang diduga memiliki aktivitas anticacing dari fraksi air adalah saponin, tanin, triterpenoid, dan alkaloid. Saponin dapat menyebabkan iritasi pada selaput lendir sehingga mengganggu proses penyerapan nutrien dalam usus cacing. Saponin juga dapat menyebabkan tertekannya sistem syaraf dan sistem gerak sehingga terjadi kelemahan umum pada cacing, sedangkan tertekannya sistem pernapasan menyebabkan kekurangan oksigen sehingga cacing mati. Ridwan \& Ayunita (2007) mengamati komponen fitokimia beberapa sari daun miana (Coleus blumei benth) dan menunjukkan bahwa sari daun miana mengandung senyawa flavonoid (fenol), steroid, saponin, dan tanin. Selain itu, sari daun miana juga mempunyai aktivitas anticacing yang kuat secara in vitro.

Senyawa metabolit sekunder dalam EDJ dengan pelarut air yang mempercepat aktivitas anticacing adalah triterpenoid, sedangkan komponen lain memberi pengaruh kematian yang lebih lama. Hal ini didukung dari data kandungan fitokimia bahwa EDJ dengan pelarut air memiliki aktivitas anticacing paling kuat karena kaya dengan triterpenoid, sedangkan fraksi metanol yang memiliki aktivitas anticacing lemah, mengandung banyak steroid dan tidak terdapat triterpenoid.

\section{Total Telur Tiap Gram Ekskreta (TTGE) Ayam Lokal}

Jumlah TTGE praperlakuan antar individu pada berbagai perlakuan sangat bervariasi (Tabel 3). Hasil pemeriksaan kondisi cacing pada hari ke-7, ternyata jumlah TTGE semua perlakuan menurun termasuk kontrol. Penurunan TTGE juga terjadi pada kelompok kontrol sebesar 87,5\% walaupun tidak diberi bahan anticacing. Hal ini kemungkinan karena nutrisi yang diberikan pada ternak untuk semua perlakuan merupakan ransum berkualitas baik sehingga meningkatkan kekebalan tubuh yang dapat menekan fertilisasi cacing A. galli walaupun tanpa pemberian bahan anticacing. Penggunaan tepung daun jarak sampai 16\% dan penggunaan obat cacing komersial dapat menurunkan 100\% TTGE. Hal ini menunjukkan bahwa EDJ memiliki 
aktivitas anticacing yang cukup tinggi sehingga dapat membunuh cacing $A$. galli.

Kemampuan tepung daun jarak sebagai anticacing berkaitan dengan kandungan saponin dan tanin. Saponin merupakan flavonoid tanaman yang memiliki efek antifertilisasi dengan menyebabkan pengkerutan membran sel telur dan larva sehingga integritas membran menurun. Hal ini dapat menghambat perkembangan telur dan larva cacing $A$. galli. Tertekannya sistem syaraf dan sistem gerak menyebabkan cacing menjadi lemah dan tertekannya sistem pernafasan menyebabkan kekurangan oksigen sehingga cacing mati. Saponin juga dapat menyebabkan sel-sel cacing menjadi terhidrolisis sehingga cacing mati dan tubuh cacing terlihat transparan

Tanin merupakan senyawa polifenol sekunder tanaman yang memiliki kemampuan afinitas tinggi dengan protein dan polisakarida (Hoste et al., 2006). Tanin kondensasi memiliki kemampuan menekan aktivitas larva cacing yang ada pada saluran pencernaan rusa yang dipelihara dalam sistem pastura sehingga mengambat pertumbuhan cacing (Molan et al., 2003). Sementara itu, Iqbal et al. (2006) melaporkan bahwa tanin kondensasi dapat menghambat penetasan telur cacing Haemonchus contortus secara in vitro yang bersifat linier dengan dosis yang diberikan, namun tidak berpengaruh pada cacing $H$. contortus dewasa. Namun Molan et al. (2000) menyatakan bahwa ekstrak tanin dari tanaman

Tabel 3. Jumlah telur tiap gram ekskreta Ascaridia galli pada setiap kelompok ayam pra dan pasca perlakuan

\begin{tabular}{|c|c|c|c|}
\hline \multirow{2}{*}{\multicolumn{2}{|c|}{ Perlakuan }} & \multicolumn{2}{|c|}{ Jumlah rata-rata telur cacing } \\
\hline & & \multirow{2}{*}{$\begin{array}{c}\begin{array}{c}\text { Praperlakuan } \\
\text { (2 hari sebelum } \\
\text { perlakuan) }\end{array} \\
100\end{array}$} & \multirow{2}{*}{$\begin{array}{c}\begin{array}{c}\text { Pascaperlakuan } \\
\text { (7 hari setelah } \\
\text { perlakuan) }\end{array} \\
-\end{array}$} \\
\hline TDJ 0\% & U1 & & \\
\hline & U2 & 100 & - \\
\hline & U3 & 800 & 100 \\
\hline \multirow[t]{3}{*}{ TDJ $2 \%$} & U1 & 100 & - \\
\hline & U2 & 30.000 & - \\
\hline & U3 & 200 & - \\
\hline \multirow[t]{3}{*}{ TDJ $4 \%$} & U1 & 500 & - \\
\hline & U2 & 400 & - \\
\hline & U3 & 400 & - \\
\hline \multirow[t]{3}{*}{ TDJ 8\% } & U1 & 16.000 & - \\
\hline & U2 & 100 & - \\
\hline & U3 & 100 & - \\
\hline \multirow[t]{3}{*}{ TDJ 16\% } & U1 & 800 & - \\
\hline & U2 & 33.000 & - \\
\hline & U3 & 1.300 & - \\
\hline \multirow[t]{3}{*}{ Piperazin } & U1 & 600 & - \\
\hline & U2 & 56.000 & - \\
\hline & U3 & 200 & - \\
\hline
\end{tabular}

Keterangan: TDJ= tepung daun jarak
Leucaena cuneata dapat mengurangi perkembangan larva cacing nematoda $\left(\mathrm{L}_{3}\right)$ sampai 91\%, mengurangi jumlah telur yang meneta sampai 34\% dan menurunkan motilitas dari larva $\mathrm{L}_{3}$ sampai $30 \%$.

\section{Performa Ayam Lokal}

Hasil analisis ragam menunjukkan bahwa pencekokan larutan tepung daun jarak dengan konsentrasi $8 \%$ dan $16 \%$ dan penggunaan obat cacing komersial berpengaruh nyata $(\mathrm{P}<0,05)$ menurunkan tingkat konversi ransum, namun tidak berpengaruh nyata terhadap konsumsi ransum, bobot badan akhir, dan PBB (Tabel 4). Teknik pemberian tepung daun jarak melalui pencekokan tidak menimbulkan efek negatif terhadap palatabilitas ransum sehingga tidak mempengaruhi konsumsi ransum.

Tepung daun jarak mengandung senyawa saponin yang diketahui mempunyai rasa sepat sehingga dapat menurunkan palatabilitasnya dan daya konsumsi pada ternak. Sementara itu (Ueda et al., 2002) menyatakan bahwa penurunan konsumsi ransum yang mengandung saponin lebih disebabkan oleh aspek fisiologis dan bukan rasanya yang sepat. Saponin dari tanaman teh yang terdapat dalam ransum dapat menunda laju pengosongan tembolok pada ayam. Hal ini menyebabkan penurunan rangsangan nafsu makan akibat penggembungan tembolok oleh sisa ransum yang tertinggal. Lebih jauh Ueda et al. (2004) menyimpulkan bahwa penurunan konsumsi ransum berperan penting pada terhambatnya pertumbuhan akibat pemberian saponin. Penundaan pengosongan tembolok yang berkaitan dengan tingkat konsumsi ransum juga akibat dari beberapa saponin tetapi tidak semua saponin tanaman menghasilkan efek yang sama. Faktor lain yang juga menyebabkan tidak terdapatnya perbedaan secara nyata antar perlakuan dalam konsumsi adalah tingkat energi. Jumlah energi ransum yang digunakan pada penelitian sama untuk setiap perlakuan sehingga tidak terdapat perbedaan yang nyata dalam tingkat konsumsi.

Penggunaan tepung daun jarak sampai level $8 \%$ dengan teknik pencekokkan belum dapat meningkatkan PBB, tetapi penggunaannya pada level 16\% dapat meningkatkan PBB ayam lokal sebesar 11\% dibanding kontrol. Sementara itu, penggunaan obat cacing komersial dapat meningkatkan PBB sebesar 24\% dibanding kontrol. Peningkatan bobot badan ini dimungkinkan karena tidak adanya telur cacing pada ekskreta yang mencerminkan rendahnya tingkat infeksi cacing sehingga proses pencernaan dan penyerapan nutrien ransum dapat dioptimalkan.

Penggunaan tepung daun jarak pada level 8\% dan $16 \%$ dapat menurunkan konversi ransum dengan nilai yang hampir sama pada penggunaan obat cacing komersial. Hal ini menunjukkan bahwa penggunaan tepung daun jarak pada level tersebut dapat memperbaiki efisiensi penggunaan ransum dibandingkan perlakuan kontrol.

Peningkatan performa ayam lokal yang mendapat tepung daun jarak disebabkan oleh senyawa tanin dan saponin yang mampu mengurangi jumlah TTGE cacing dan mampu membunuh cacing A galli. Kemungkinan 
Tabel 4. Konsumsi ransum, pertambahan bobot badan (PBB), dan konversi ransum pada ayam kampung yang mendapat perlakuan tepung daun jarak

\begin{tabular}{ccccc}
\hline Perlakuan & $\begin{array}{c}\text { Konsumsi } \\
\text { (g/ekor/minggu) }\end{array}$ & $\begin{array}{c}\text { PBB } \\
\text { (g/ekor/minggu) }\end{array}$ & $\begin{array}{c}\text { Bobot badan akhir } \\
\text { (g/ekor) }\end{array}$ & Konversi ransum \\
\hline TDJ 0\% & $525,50 \pm 60,20$ & $91,33 \pm 37,11$ & $1136,7 \pm 296,58$ & $5,57 \pm 0,82^{\mathrm{ab}}$ \\
TDJ 2\% & $479,33 \pm 3,06$ & $90,00 \pm 10,58$ & $1133,3 \pm 81,72$ & $5,33 \pm 0,46^{\mathrm{ab}}$ \\
TDJ 4\% & $558,50 \pm 107,33$ & $84,33 \pm 5,51$ & $1106,7 \pm 64,93$ & $6,63 \pm 0,94^{\mathrm{a}}$ \\
TDJ 8\% & $480,67 \pm 45,10$ & $98,33 \pm 26,27$ & $1156,7 \pm 112,91$ & $4,88 \pm 1,29^{\mathrm{b}}$ \\
TDJ 16\% & $488,00 \pm 162,61$ & $101,67 \pm 10,30$ & $1206,7 \pm 343,53$ & $4,79 \pm 3,23^{\mathrm{b}}$ \\
Obat cacing komersial & $532,00 \pm 116,73$ & $113,00 \pm 26,51$ & $1261,7 \pm 96,96$ & $4,56 \pm 1,88^{\mathrm{b}}$ \\
\hline
\end{tabular}

Keterangan: superskrip berbeda pada kolom yang sama menunjukkan berbeda nyata $(\mathrm{P}<0,05)$.

potensi anticacing dari senyawa tanin, terutama tanin kondensasi, telah dibuktikan pada uji in vitro maupun in vivo menggunakan ekstrak beberapa tanaman yang mengandung tannin (Molan et al., 2000; Athanasiadou et al., 2001; Schreurs et al., 2002).

Hasil penelitian ini diperkuat oleh penemuan Min \& Hartz (2003) bahwa ekstrak tanin dari berbagai tanaman dapat memutus siklus hidup cacing nematoda di dalam saluran pencernaan dengan menghambat penetasan telur cacing dan perkembangan larva infektif. Tanaman yang mengandung 5\% ekstrak tanin dapat mengurangi kontaminasi larva dan dapat digunakan sebagai anticacing. Pengendalian parasit disarankan menggunakan tanaman yang mengandung tanin karena dapat mengurangi parasit saluran pencernaan dan meningkatkan performa ternak. Populasi cacing berkurang sehingga absorpsi zat makanan optimal sehingga jumlah nutrien yang diserap dan dideposit dalam tubuh lebih banyak yang menyebabkan bobot badan akhir ayam lokal lebih tinggi.

Beberapa penelitian telah dilakukan untuk mengevaluasi senyawa sekunder tanaman seperti flavonoid, tannin dan saponin sebagai anticacing alami. Brito et al. (2009) mengevaluasi ekstrak air dan etanol dari buah noni (Morinda citrifolia) pada ayam yang terinfeksi $A$. galli secara alami dan menunjukkan bahwa secara in vitro buah noni yang diekstrak dengan taraf $26,96 \mathrm{mg} / \mathrm{ml}$ mampu mematikan cacing 50\%, sedangkan ekstrak etanol buah noni dengan taraf $66,72 \mathrm{mg} / \mathrm{ml}$ mampu mematikan cacing sebesar $76,67 \%$. Ekstrak air buah noni pada uji in vivo dapat mematikan cacing sebesar $27,08 \%$, sedangkan ekstrak etanol tidak menunjukkan kemampuan anticacing dibanding perlakuan kontrol. Hal ini menunjukkan bahwa pada uji in vivo memerlukan taraf ekstrak yang lebih tinggi dibanding uji in vitro. Selanjutnya Githiori et al. (2006) menyatakan bahwa konsentrasi dari bahan aktif yang digunakan untuk uji in vitro tidak selalu berkorelasi dengan bioavaibilitasnya pada uji in vivo. Dengan demikian, setiap uji in vitro sebaiknya selalu dilanjutkan dengan uji in vivo untuk meningkatkan validitas aktivitas anticacing asal bahan tanaman. Adu et al. (2009) melaporkan bahwa lateks dari tanaman pawpaw (Carica papaya) yang diberikan pada ayam jantan muda dengan dosis $400 \mathrm{mg}$ /ekor/hari dapat menurunkan TTGT sebesar 77,8\%. Selanjutnya Iqbal et al. (2006) menyatakan bahwa terjadi penurunan jumlah telur cacing pada feses kambing yang diberi ransum mengandung tanin kondensasi. Sementara itu, konsumsi pakan serta kecernaan nutrien menurun dan neraca nitrogen meningkat dibandingkan kontrol. Pertambahan bobot badan tertinggi dicapai oleh ternak kambing yang diberi ransum mengandung 3\% tanin kondensasi.

\section{Mortalitas}

Selama enam minggu pemeliharaan pada penelitian ini tidak ada ayam yang mati, berarti tidak terjadi mortalitas. Cacing parasitik pada umumnya dapat mengakibatkan penurunan bobot badan sehingga menimbulkan kerugian ekonomi yang cukup besar pada peternak. Kenyataan ini memberikan arti bahwa tepung daun jarak lebih efektif diberikan pada ayam lokal sebagai anticacing dibandingkan pada ayam broiler.

\section{KESIMPULAN}

Tepung daun jarak yang diekstraksi dengan air atau metanol mengandung senyawa fitokimia saponin dan tanin yang dapat digunakan sebagai anticacing alami. Tepung daun jarak yang diekstraksi dengan pelarut air memiliki aktivitas anticacing lebih kuat dibanding pelarut metanol terhadap cacing Ascaridia galli. Konsentrasi ekstrak daun jarak sebesar 2\% sudah efektif sebagai anticacing secara in vitro. Pemberian tepung daun jarak pada ayam lokal dengan pencekokan cukup efektif digunakan sebagai anticacing tanpa mengganggu palatabilitas ransum. Konsentrasi ekstrak daun jarak sebesar $16 \%$ (b/v) menghasilkan PBB dan konversi ransum yang sama dengan penggunaan obat cacing komersial.

\section{DAFTAR PUSTAKA}

Ademola, I. O., B. O. Fagbemi, \& S. O. Idowu. 2004. Evaluation of the anthelmintic activity of Khaya senegalensis extract against gastrointestinal nematodes of sheep: in vitro and in vivo studies. Vet. Parasitol. 122:151-164 (Abstr).

Adu, O. A., K. A. Akingboye, \& A. Akinfemi. 2009. Potency of pawpaw (Carica papaya) latex as an anthelmintic in poultry production. Bot. Res. Int. 2:139-142.

Athanasiadou, S., I. Kyriazakis, F. Jackson, \& R. L.Coop. 2001. Direct anthelmintic effects of condensed tannins towards 
different gastrointestinal nematodes of sheep: in vitro and in vivo studies. Vet. Parasitol. 99:205-219.

Brito, D. R., R. M. Fernandes, M. Z. Fernandes, M. D. Ferreira, F. R. Rolim, \& M. L. Filho. 2009. Anthelmintic activity of aqueous and ethanolic extracts of Morinda citrifolia fruit on Ascaridia galli. Rev. Bras. Parasitol Vet. 18:32-36.

Cringoli, G., L. Rinaldi, V. Veneziano, G. Capelli, \& A. Scala. 2004. The influence of flotation solution, sample dilution and the choice of McMaster slide area (volume) on the reliability of the McMaster technique in estimating the faecal egg counts of gastrointestinal strongyles and Dicrocoelium dendriticum in sheep. Vet. Parasitol. 23:121-31.

Fagbenro-Beyioku, A. F., W. A. Ovibo, \& B. C. Anuforom. 1998. Desinfectant/antiparasitic activities of Jatropha curcas . J. East Afr. Med. 75:508-511.

Githiori, J. B., S. Athanasiadou, \& S. M. Thamsborg. 2006. Use of plants in novel approaches for control of gastrointestinal helminths in Livestock with emphasis on small ruminants. Vet. Parasitol. 139:308-320.

Hoste, H., F. Jackson, S. Athanasiadou, S. M. Thamsborg, \& S. O. Hoskin. 2006. The effects of tannin-rich plants on parasitic nematodes in ruminants. Trends Parasitol. 22:253-261.

Iqbal, Z., M. A. Jabbar, S. Ahmed, M. Nisa, M. S. Sajid, M.N. Khan, K. A. Muftia \& M. Yaseen. 2006. Direct and indirect anthelmintic effects of condensed tannins in sheep. Vet. Parasitol. 144:125-131 (Abstr).

Kalia, K., K. Sharma, H. P. Singh, \& B. Singh. 2008. Effects of extraction methods on phenolic contents and antioxidant activity in aerial parts of Potentilla atrosanguinea Lodd. and quantification of its phenolic constituents by RP-HPLC. J. Agric. Food Chem. 56:10129-10134.

Kopkhar, S. M. 2002. Konsep Dasar Kimia Analitik. Terjemahan: A. Saptorahardjo. UI Press, Jakarta.

Mattjik, A. A. \& I. M. Sumertajaya. 2002. Perancangan Percobaan dengan Aplikasi SAS dan Minitab. Jilid I. Edisi ke-2. Institut Pertanian Bogor (IPB)-Press, Bogor.

Min, B. R. D. \& S. P. Hart. 2003. Tanins for suppression of internal parasites. J. Anim. Sci. 81:E102-E109.
Molan, A. L., G. C. Waghorn, B. R. Min, \& W. C. McNabb. 2000. The effect of condensed annin from seven herbages on Trichostrongylus colubriformis larval migration in vitro. Folia Parasitol. 47:39-44.

Molan, A. L., A. J. Duncan, T. N. Barry, \& W. C. McNabb. 2003. Effects of condensed tannins and crude sesquiterpene lactones extracted from chicory on themotility of larvae of deer lungworm and gastrointestinal nematodes. Parasitol. Int. 52:209-218.

[NRC] National Research Council. 1994. Nutrient Requirement of Poultry. $9^{\text {th }}$ Revised Ed. National Academy Press, Washington.

Oliveira, L. M. B., C. M. L. Bevilaqua, C. T. C. Costa, I. T. F. Macedo, R. S. Barros, A. C. M. Rodrigues, A. L. F. Camurça-Vasconcelos, S. M. Morais, Y. C. Lima, L. S. Vieira, \& A. M. C. Navarro. 2009. Anthelmintic activity of Cocos nucifera L. against sheep gastrointestinal nematodes. Vet. Parasitol. 159:55-59 (Abstr).

Ridwan, Y. \& Y. Q. Ayunita. 2007. Fitokimia dan aktivitas anthelmintika terhadap cacing pita ayam dari beberapa varietas miana (Coleus blumei benth) secara in vitro. Jurnal Protein 14:17-20.

Schreurs, N. M., A. L. Molan, N. Lopez-Villalobos, T. N. Barry, \& W. C. McNabb. 2002. Effects of grazing undrenched weaner deer on chicory or perennial ryegrass/white clover pasture on the viability of gastrointestinal nematodes and lungworms. Vet. Rec. 151:348-353

Tabbu, C. R. 2002. Penyakit Ayam dan Penyebabnya. Penyakit Asal Parasit, Non Infeksius dan Enthiologi Kompleks. Vol. 2. Penerbit Kanisius, Yogyakarta.

Ueda, H., A. Takagi, K. Katou, \& S. Matsumoto. 2002. Feeding behavior in chicks fed tea saponin and quinine sulfate. J. Poultry. Sci. 39: 34-41.

Ueda, H., K. Katou, \& S. Matsumoto. 2004. Growth response and crop emptying in chicks force-feed diets containing various saponins. J. Poultry Sci. 41:298-306. 